\title{
USE OF MAIZE COB FOR PRODUCTION OF PARTICLEBOARD
}

\author{
Uso do sabugo de milho na produção de painéis aglomerados
}

\author{
Mário Vanoli Scatolino', Danillo Wisky Silva², Rafael Farinassi Mendes², Lourival Marin Mendes ${ }^{3}$
}

\begin{abstract}
Agricultural residues are materials generated in large quantities in Brazil and can accumulate to such extent as to cause environmental problems. Among agricultural residues, maize cob is one worthy of notice, and an alternative use for maize cob would be to produce particleboard panels in association with wood particles. This study aimed to evaluate the feasibility of using maize cob for production of particleboard panels. The following maize cob percentages were used: $0 \%, 25 \%, 50 \%, 75 \%$ and $100 \%$, in association with particles of Pinus oocarpa wood. Panels were made with $8 \%$ of urea formaldehyde and $1 \%$ of paraffin (based on dry weight of particles). For compressing the panels, a pressure of $3.92 \mathrm{MPa}$ was applied at a temperature of $160^{\circ} \mathrm{C}$, for 8 minutes. Increased replacement of pinewood by maize cob residue promoted significant improvements to the properties water absorption after two hours of immersion, thickness swelling after two and after twenty-four hours of immersion. Mechanical properties had a decreasing correlation with the maize cob percentage being incorporated.
\end{abstract}

Index terms: Environmental problems, reuse, physicomechanical properties, agricultural residues.

\section{RESUMO}

Os resíduos agrícolas são materiais gerados em grande quantidade no Brasil, podendo se acumular no ambiente, gerando graves problemas. Um desses resíduos que merecem destaque é o sabugo de milho. Uma das alternativas para o reaproveitamento do sabugo seria a produção de painéis aglomerados em mistura com madeira. Objetivou-se, neste trabalho, avaliar a viabilidade da utilização do sabugo de milho para a produção de painéis aglomerados. As porcentagens de sabugo de milho utilizadas foram de 0\%, 25\%, 50\%, 75\% e 100\% associadas com partículas de madeira de Pinus oocarpa. Os painéis foram produzidos com 8\% de uréia-formaldeído e $1 \%$ de parafina (base massa seca de partículas). Na prensagem dos painéis, foi utilizada pressão de 3,92 MPa e temperatura de $160^{\circ} \mathrm{C}$ por um período de 8 minutos. O aumento da substituição da madeira de pinus pelo resíduo sabugo de milho promoveu melhoras significativas para as propriedades de absorção de água, após duas horas e inchamento em espessura, após duas e vinte e quatro horas. As propriedades mecânicas apresentam relação decrescente com a porcentagem de incorporação de sabugo de milho.

Termos de indexação: Problemas ambientais, reaproveitamento, propriedades físico-mecânicas, resíduos agrícolas.

(Received in february 15, 2013 and approved in may 3, 2013)

\section{INTRODUCTION}

Brazil is in essence an agroindustrial country and as a consequence it has several types of lignocellulosic residue with potential for use, including maize cob, husks of rice, coffee, peanut, coconut and castor oil plant, as well as banana stem, cassava stem and sugarcane bagasse, among others (MENDES et al., 2010a; MENDES et al., 2010b.).

Among the already mentioned residues, maize cob is worthy of special mention due to its high volume productivity, with corn (Zea mays L.) being ranked third among the most widely cultivated cereals worldwide, after wheat and rice (FOOD AND AGRICULTURE ORGANIZATION - FAO, 2008). This agricultural residue can accumulate in large quantities and, as a result, cause environmental problems.
According to Buranello (2009), the worldwide production of corn is around 800 million tons, therefore it is necessary to assign for correct use the waste material produced by this crop.

Brazil's corn output has increased in the past 35 years at a yearly rate of $3.2 \%$ (COMPANHIA NACIONAL DE ABASTECIMENTO-CONAB, 2011) and, additionally, by 2021 the country should be expanding its corn crop area by around 500 thousand hectares. Bastos et al. (2007) argue that in every $100 \mathrm{~kg}$ of corn ears, around $18 \mathrm{~kg}$ are maize cobs. And with increased crop productivity, amounts of residue will surely also increase.

Crop residues need to be recycled somehow, and directing such waste material to production of particleboard panels is a possible alternative, given that as a rule particleboard panels can be produced from any

\footnotetext{
1Universidade Federal de Lavras/UFLA - Cx. P. 3037 - 37200-000 - Lavras, MG - Brasil - mario_paraiso@hotmail.com 2Universidade Federal de Lavras/UFLA - Lavras - MG - Brasil
}

3Universidade Federal de Lavras/UFLA - Departamento de Ciências Florestais/DCF - Lavras - MG - Brasil

Ciênc. agrotec., Lavras, v. 37, n. 4, p. 330 - 337, jul./ago., 2013 
lignocellulosic material capable of providing them with high mechanical strength and a preestablished specific weight (ROWELL; HAN; ROWELL, 2000).

Considering the above context, the objective of this study is to evaluate the feasibility of using maize cob for production of particleboard panels in association with pinewood particles (Pinus oocarpa Schiede ex Schltdl.).

\section{MATERIAL AND METHODS}

\section{Raw material and particle processing}

Maize cobs (Zea mays L.) were obtained from the Engineering Department of the Federal University of Lavras, (DEG - UFLA), while pine trees (Pinus oocarpa Schiede ex Schltdl.) were collected from stands in the campus of UFLA at age 25 years. Maize cobs and pinewood were subjected to analysis to determine basic density values, following procedures in standard NBR 11941 (ASSOCIAÇÃOBRASILEIRA DE NORMAS TÉCNICAS - ABNT, 2003).

The pine trees were cut into short logs, which were then heated in a tank filled with water at a temperature of $60^{\circ} \mathrm{C}$ for 24 hours, and later processed in a lathe so as to derive sheets $2 \mathrm{~mm}$ in thickness. The sheets were crushed in a hammermill using a $6 \mathrm{~mm}$ mesh sieve. The maize cobs were processed in the same hammermill under similar conditions.

The resulting slivers of pinewood and maize cob were sieved using a $2 \mathrm{~mm}$ mesh mechanical vibrating sieve in order to remove fine particles, and were then dried in an oven until they reached a $3 \%$ moisture content.

\section{Chemical analysis of wood}

For analysis of the chemical constituents of pinewood and maize cob, sawdust obtained from processing the wood in a Wiley mill was used. Material retained by the 40 through 60 mesh sieving screens was used. Following acclimatization at a temperature of $22 \pm$ $2^{\circ} \mathrm{C}$ and $65 \pm 5 \%$ relative humidity, the material was subjected to analysis to determine the total extractives content - NBR 14853 (ABNT, 2010), lignin content - NBR 7989 (ABNT, 2010), ash content - NBR 13999 (ABNT, 2003) and holocellulose content (obtained by the difference $\mathrm{H}(\%)$ $=100-\%$ Total extractives $-\%$ Lignin content).

\section{Experimental design and production of particleboard panels}

The experimental design consisted of five treatments, in which four percentages of maize cob residue were used in replacement of pinewood, as is illustrated in table 1 . Three panels with a nominal density of $0.70 \mathrm{~g} / \mathrm{cm}^{3}$ were made for each treatment.

Table 1 - Experimental design.

\begin{tabular}{ccc}
\hline Treatment & Pinus oocarpa $(\%)$ & Maize $\operatorname{cob}(\%)$ \\
\hline 1 & 100 & - \\
2 & 75 & 25 \\
3 & 50 & 50 \\
4 & 25 & 75 \\
5 & - & 100 \\
\hline
\end{tabular}

In order to produce the panels, $8 \%$ of ureaformaldehyde adhesive and $1 \%$ of paraffin (based on dry weight of particles) was used, in all treatments, spraying them onto the particles inside a rotating drum.

Once adhesive and paraffin were mixed with the particles, the mixture was placed into a sheet mold and manually compressed at $3 \mathrm{kgf} / \mathrm{cm}^{2}$. The resulting sheet was then subjected to a hot compression cycle at a temperature of $160^{\circ} \mathrm{C}$, at a pressure of $40 \mathrm{kgf} / \mathrm{cm}^{2}$, for 8 minutes.

\section{Evaluation of panels and statistical analysis}

Once panels were acclimatized at a temperature of $22 \pm 2^{\circ} \mathrm{C}$ and $65 \pm 5 \%$ relative humidity, test pieces were removed using a circular saw. Analyses of the properties water absorption, thickness swelling and internal bond were based on standard American Society For Testing And Materials-ASTM - D1037 (2006), while analyses of the properties modulus of rupture and modulus of elasticity in static bending were based on standard DIN 52362 (1982).

The experiment was laid out in a completely randomized design, on which the statistical analysis was based. There being a statistical difference among mean values of apparent density, a correlation analysis was conducted between panel densities and each of the properties in question. Where properties showed a significant correlation, an analysis of covariance was performed with means adjusted for panel density.

As the objective of this study was to verify variations in results of physical and mechanical properties as a function of increasing maize cob percentage, data were subjected to analysis of variance and analysis of regression, both at the 5\% significance level. 


\section{RESULTSAND DISCUSSION}

\section{Chemical analysis}

Table 2 provides percentage values of chemical components present in maize cob and Pinus oocarpa wood.

Table 2 - Chemical analysis of materials.

\begin{tabular}{crcr}
\hline Component & \multicolumn{2}{c}{$\begin{array}{c}\text { Pinus oocarpa } \\
(\%)\end{array}$} & Maize cob (\%) \\
\hline Extractives & 5.2 & $(4.8)^{*}$ & $7.0(2.2)$ \\
Lignin & 28.3 & $(2.3)$ & $14.7(4.2)$ \\
Ash & 0.4 & $(24.0)$ & $1.6(3.3)$ \\
Holocellulose & 66.2 & $(1.4)$ & $76.7(0.8)$ \\
\hline \multicolumn{4}{c}{ * Values in brackets correspond to coefficients of variation. }
\end{tabular}

*Values in brackets correspond to coefficients of variation.

Results of percentage quantities of lignin and extractives found in maize cobs were similar to values found in literature, contrary to results found for ash percentage. Carroll and Somerville (2009) found 5.6\% for extractives, Yrjas, Lisa and Hupa (1995) found $16.6 \%$ for lignin, and Bastos et al. (2007) found 3.06\% for ash content in agricultural residue.

As regards pinewood, values found in this study agree with results found in literature. In a study with softwoods, Colodette et al. (2002) found that lignin contents ranged between $15 \%$ and $35 \%$, while extractives and inorganic constituents were found in fractions less than $10 \%$. While studying the chemical composition of Pinus oocarpa cultivated in the cerrado, Morais, Nascimento and Melo (2005) found $11.47 \%$ of extractives, $25.18 \%$ of lignin and $1.26 \%$ of ash. Higher lignin contents are desirable for particleboard production, this component having a very condensed structure and irregular aspect which provides high rigidity to the relevant material, acting as a buffer of cellulose microfibrils, limiting parallel to grain movement and increasing mechanical strength against external forces (SWEET; WINANDY, 1999).

In comparing results, it was noted that maize cobs have a lower lignin content than pinewood, while at the same time having a higher extractives content, which means that increasing maize cob percentages could negatively influence the physical and mechanical properties of panels.

\section{Physical properties}

\section{Density and Compaction Ratio}

Mean values of basic density found for wood and maize cob were $0.473 \mathrm{~g} / \mathrm{cm}^{3}$ and $0.170 \mathrm{~g} / \mathrm{cm}^{3}$ respectively.
Mean values of apparent density for each treatment along with the relevant values of compaction ratio are given in table 3 .

Table 3 - Mean apparent density and compaction ratio of panels.

\begin{tabular}{ccc}
\hline \% Maize cob & $\begin{array}{c}\text { Apparent density } \\
\mathrm{g} / \mathrm{cm}^{3}\end{array}$ & Compaction Ratio \\
\hline 0 & $0.63 \mathrm{a}$ & $1.4 \mathrm{a}$ \\
25 & $0.70 \mathrm{~b}$ & $1.8 \mathrm{~b}$ \\
50 & $0.67 \mathrm{ab}$ & $2.1 \mathrm{c}$ \\
75 & $0.68 \mathrm{ab}$ & $2.8 \mathrm{~d}$ \\
100 & $0.65 \mathrm{ab}$ & $3.9 \mathrm{e}$ \\
\hline
\end{tabular}

Means followed by the same letter in a column do not differ statistically by the Tukey test at the $5 \%$ significance level.

Mean values of apparent density ranged from $0.636 \mathrm{~g} / \mathrm{cm}^{3}$ to $0.700 \mathrm{~g} / \mathrm{cm}^{3}$, thereby placing the panels of all treatments under a medium-density category, which encompasses the range $0.59 \mathrm{~g} / \mathrm{cm}^{3}$ to $0.80 \mathrm{~g} / \mathrm{cm}^{3}$ (IWAKIRI, 2005). Only panels made solely with pinewood had mean values of compaction ratio considered as being ideal by Maloney (1993), between 1.3 and 1.6. Maize cob being a low-density agricultural residue $\left(0.17 \mathrm{~g} / \mathrm{cm}^{3}\right)$, in comparison with pinewood $\left(0.473 \mathrm{~g} / \mathrm{cm}^{3}\right)$, explains such results. Since compaction ratio is defined as the ratio of panel density to the density of the relevant material, this value increases to the extent that maize cob percentage rises against pinewood.

\section{Water absorption two and twenty-four hours after immersion}

The linear regression run between panel density and water absorption after two and after twenty-four hours of water immersion was found not to be significant, revealing no linear correlation between these two properties and panel density. The regression models fitted for water absorption after two (WA2h) and after twentyfour hours (WA24h) as a function of increasing maize cob percentage are illustrated in figures 1 and 2 respectively.

A significant decrease was noted in WA2h values with increasing maize cob percentages in the panels. Such a decrease can be explained by the increasing compaction ratio of the panels to the extent that more agricultural residue was added (Table 3 ), promoting an initial barrier to water entry. 


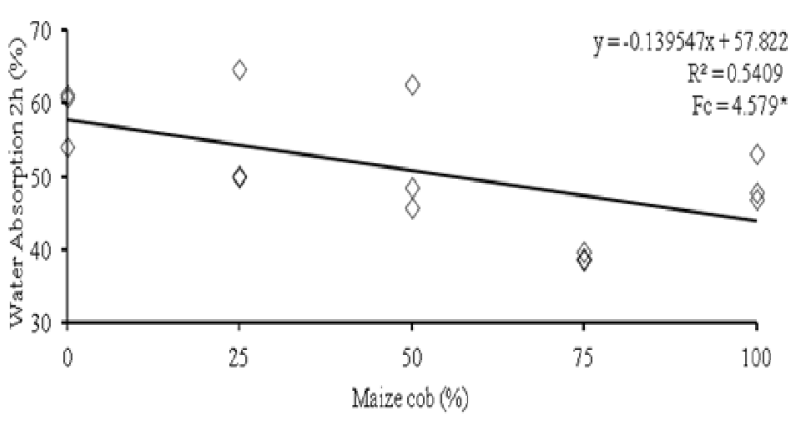

Figure 1 - Mean values of water absorption after two hours of immersion as a function of maize cob percentage. * Significant F-value at the 5\% significance level.

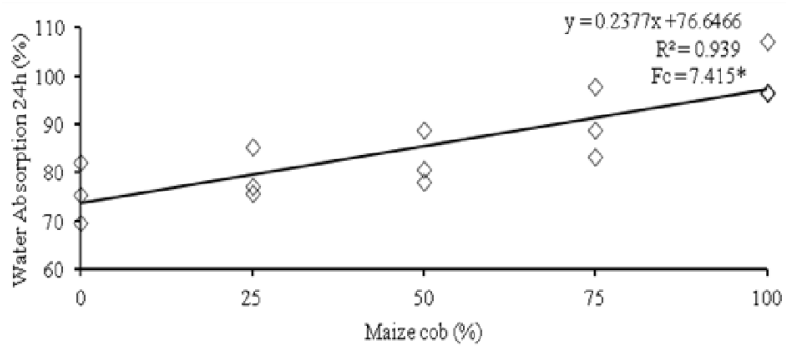

Figure 2 - Mean values of water absorption after twentyfour hours of immersion as a function of maize cob percentage.

* Significant F-value at the 5\% significance level.

However, an opposite pattern was noted for WA24h, as these mean values increased with increasing maize cob percentages in the panels. Here, water already had enough time to permeate through the entire panel structure and, with maize cob being a low-density residue, a larger number of particles are needed to compose the panel to the extent that more residue is added, thereby allowing more hygroscopic sites for water to bind.

The amount of holocellulose in maize cob was found to be higher than in pinewood (Table 2), with much of the content corresponding to polyoses, which have hygroscopic sites that promote higher water absorption.

Mendes et al. (2010b) also found an increasing tendency for water absorption after twenty-four hours of immersion when evaluating particleboard panels made with coffee husk in association with eucalyptus. They found results ranging between $70 \%$ and $96 \%$ to the extent that wood was being replaced by coffee husk at rates of $25 \%$ to $75 \%$. That range of absorption was similar to results found in this work, namely $75 \%$ to $97 \%$, for the same replacement rates.
When studying particleboard panels made with increasing levels of sugarcane bagasse in association with eucalyptus wood, Mendes et al. (2010a) found that values of WA24h ranged between $16 \%$ and $38 \%$ to the extent that bagasse percentage was increased, using $9 \%$ of ureaformaldehyde.

Güler and Buyüksari (2011) found that values of WA2h and WA24h were close to $56 \%$ and $68 \%$ respectively when evaluating particleboard panels made with peanut husk, with a density of $0.7 \mathrm{~g} / \mathrm{cm}^{3}$, using $8 \%$ of ureaformaldehyde in the core and $10 \%$ in the faces.

As far as panels from agricultural residues are concerned, overall, panels made with maize cob had higher $\mathrm{WA} 2 \mathrm{~h}$ and WA24h values than found in literature.

\section{Thickness swelling two and twenty-four hours after immersion}

The significant linear regression for thickness swelling after two hours of immersion reveals a linear correlation between that property and panel density. The estimate of the linear regression coefficient reveals that for an increase of $0.01 \mathrm{~g} / \mathrm{cm}^{3}$ in panel density there is a reduction of $0.97 \%$ in thickness swelling after two hours of immersion. The linear regression was also significant for thickness swelling after twenty-four hours of immersion. The estimate of the linear regression coefficient reveals that for an increase of $0.01 \mathrm{~g} / \mathrm{cm}^{3}$ in panel density there is a reduction of $2.07 \%$ in that property.

The regression models fitted for thickness swelling after two (TS2h) and after twenty-four hours of water immersion (TS24h) as a function of increasing maize cob percentage are illustrated in figures 3 and 4 respectively.

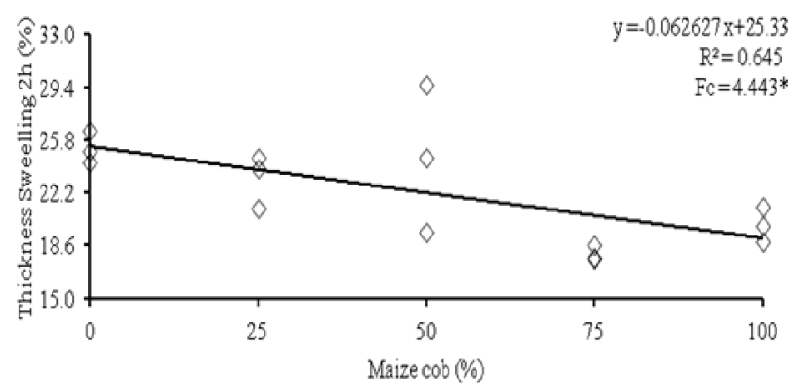

Figure 3 - Mean values of thickness swelling after two hours as a function of maize cob percentage in panels.

* Significant F-value at the 5\% significance level.

A significant decrease was noted in values of TS2h and TS24h with increasing maize cob percentages in the 
panels. Such a decrease can be explained by the increasing compaction ratio of the panels to the extent that more agricultural residue was added (Table 3), promoting an initial barrier to water entry, and also by the chemical constitution of the material (Table 2), with maize cob having a higher extractives content.

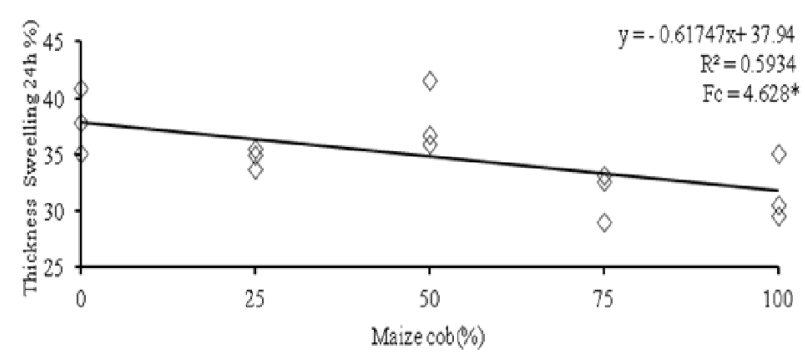

Figure 4- Mean values of thickness swelling after twentyfour hours of immersion as a function of maize cob percentage in panels.

* Significant F-value at the 5\% significance level.

Mendes et al. (2010b), when evaluating particleboard panels with differing percentages of coffee husk being added to eucalyptus wood, found that TS2h ranged from $20 \%$ to $25 \%$ and that TS24h ranged from $37 \%$ to $32 \%$. Melo et al. (2009), when evaluating differing percentages of rice husk being added to eucalyptus wood, found $9 \%$ to $17 \%$ for TS2h, and $45 \%$ to $49 \%$ for TS24h. Sekaluvu, Tumutegyereize, and Kiggundu (2013) found $26 \%$ for TS24h when evaluating particleboard panels made with maize cob using particles in the size range of 3.35 $8.00 \mathrm{~mm}$.

Standard CS 236-66 only stipulates values for TS24h, namely $35 \%$ for panels produced with ureaformaldehyde. That said, the panels produced with addition of maize cob had similar values to results found in literature for particleboards from agricultural residues. On the basis of that standard, only when maize cob percentages were $75 \%$ and $100 \%$ did panels comply with requirements.

\section{Mechanical properties}

\section{Internal bond}

The regression run between panel density and internal bond was found not to be significant, revealing no linear correlation between that property and panel density.

The regression model fitted for values of internal bond as a function of increasing maize cob percentage is illustrated in figure 5 .

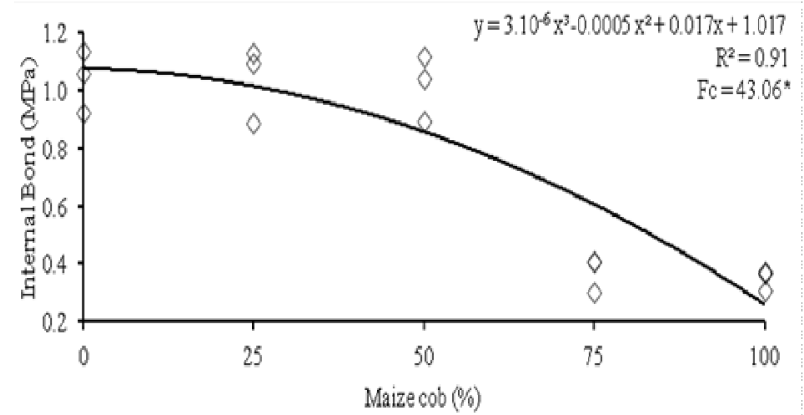

Figure 5 - Mean values of internal bond as a function of maize cob percentage in panels.

* Significant F-value at the 5\% significance level.

Decreasing values of internal bond were noted but only in treatments with $75 \%$ and $100 \%$ of maize cob. This decreasing tendency was also noted by Mendes et al. (2010b) when they evaluated values of internal bond as a function of increasing percentage of coffee husk in particleboard panels. These authors found a range of 0.15 to $0.30 \mathrm{MPa}$, both values being lower than all values found in this work. A possible explanation for such decrease is the low density of the residues, there being more particles and thus a reduced availability of adhesive per particle, potentially affecting the panel when it is subjected to tensile forces.

Güler and Buyüksari (2011) found values close to $0.30 \mathrm{MPa}$ for internal bond when they evaluated particleboard panels produced with peanut husk using differing adhesive contents in the faces $(10 \%)$ and in the core (8\%). Dacosta, Haselein and Santini (2005) found 0.20 MPa for particleboard panels produced with sawmill residue in the form of chips.

The minimum value of internal bond required by standard Commercial Standard-CS 236-66 (1968) is 0.42 MPa for UF adhesive. Therefore, panels in which the replacement of wood by maize cob was of up to $50 \%$ did comply with the market standard.

\section{Modulus of elasticity and modulus of rupture}

The regression run between panel density and MOE and MOR in static bending was found not to be significant, revealing no linear correlation between these properties and panel density. The regression models fitted for MOE and MOR values as a function of increasing maize cob percentage are illustrated in figures 6 and 7, respectively. 


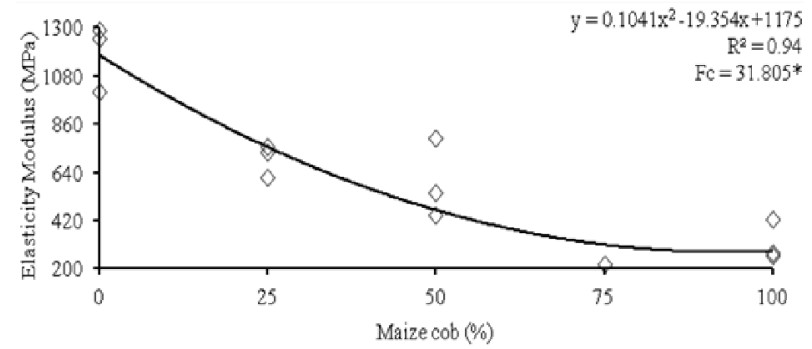

Figure 6 - Mean values of MOE as a function of maize cob percentage in panels.

* Significant F-value at the 5\% significance level.

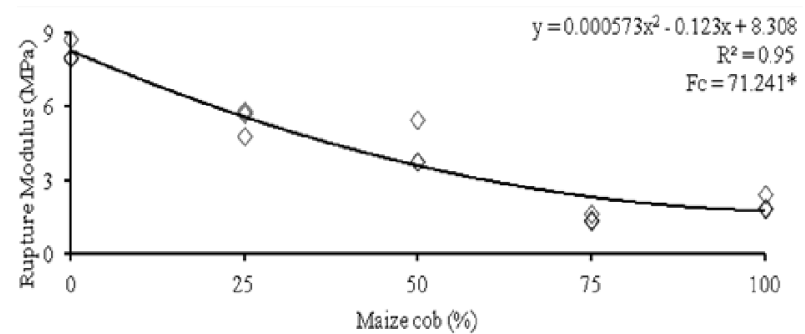

Figure 7 - Mean values of MOR as a function of maize cob percentage in panels.

* Significant F-value at the 5\% significance level.

A decrease was noted in values of MOE and MOR with increasing maize cob percentage in panels. This decreasing tendency was also noted by Mendes et al. (2010b) when they evaluated values of MOE and MOR as a function of increasing percentages of coffee husk in particleboard panels. These authors found a decrease from 800 to $300 \mathrm{MPa}$ for MOE, and from 6 to $2 \mathrm{MPa}$ for MOR, for coffee husk use rates between $75 \%$ and $25 \%$.

A fact that may have led to decreasing mechanical strength is that the ash content in maize cob is higher than in pinewood (Table 2). According to Iwakiri (2005), an ash content below $0.5 \%$ does not affect adhesive bond performance. However, the ash value found in this study was $1.6 \%$, which may have affected the bonding strength between panel particles.

Another fact may be associated with lower lignin content (Table 2), which promotes less compaction and connection between particles (MALONEY, 1993).

Melo et al. (2009) evaluated the properties of particleboard panels in which rice husk and eucalyptus wood were associated (0 to $100 \%$ ) and found values of MOE decreasing from 1,225 to $196 \mathrm{MPa}$, and values of MOR ranging from 14.7 to $3.9 \mathrm{MPa}$, as the amount of rice husk added was increased.
Güler and Buyüksari (2011) evaluated the properties of particleboard panels produced with peanut husk using different concentrations of urea-formaldehyde adhesive in the faces $(10 \%)$ and in the core $(8 \%)$ of the panel and obtained values close to 1,200 MPa for MOE and $9 \mathrm{MPa}$ for MOR.

Mendes et al. (2012) evaluated particleboard panels produced with sugarcane bagasse associated to pinewood $(25,50$ and $75 \%)$ and found MOE values ranging from 810 to $823 \mathrm{MPa}$, and MOR values ranging from 9.3 to $11 \mathrm{MPa}$.

Sekaluvu, Tumutegyereize, and Kiggundu (2013) evaluated particleboard panels produced with maize cob particles only and found means of $60 \mathrm{MPa}$ for MOE and 1.5 MPa for MOR.

Standard CS 236-66 (1968) stipulates minimum values of 2,402 MPa for MOE and $11 \mathrm{MPa}$ for MOR for particleboard panels made with urea-formaldehyde adhesive. Therefore, the values found for the panels produced with pinewood in association with maize cob particles were consistent with values found in literature for panels from agricultural residues, yet they were below the minimum requirement set by the market standard.

In conclusion, further studies are recommended with different production variables, mainly with increasing adhesive quantities and evaluating lower quantities of maize cob, as percentages higher than $50 \%$ drastically decreased mechanical properties.

\section{CONCLUSIONS}

Increasing replacement of pinewood by maize cob residue promoted significant improvements in the properties WA2h, TS2h and TS24h;

Mechanical properties had a decreasing correlation with the maize cob percentage being incorporated;

Percentages higher than $50 \%$ drastically decreased values of mechanical properties;

Overall, incorporating maize cob does not affect the physical properties of panels, despite affecting their mechanical properties.

\section{REFERENCES}

ASSOCIAÇÃOBRASILEIRA DE NORMAS TÉCNICASABNT- NBR 7989: Pasta celulósica e madeira Determinação de lignina insolúvel em ácido. Rio de Janeiro, 2010. 6 p.

ASSOCIAÇÃOBRASILEIRA DE NORMAS TÉCNICASABNT- NBR 11941: Madeira-Determinaçãoda densidade básica. Rio de Janeiro, 2003. 6p. 
ASSOCIAÇÃO BRASILEIRA DE NORMAS TÉCNICASABNT- NBR 13999: Papel, cartão, pastas celulósicas e madeira - Determinação do resíduo (cinza) após a incineração a $5^{\circ}{ }^{\circ} \mathrm{C}$. Rio de Janeiro, 2003. 4 p.

ASSOCIAÇÃO BRASILEIRA DE NORMAS TÉCNICASABNT- NBR 14853: Madeira - Determinação do material solúvel em etanol-tolueno e em diclorometano e em acetona. Rio de Janeiro, 2010. 3 p.

\section{AMERICAN SOCIETYFOR TESTINGAND}

MATERIALS-ASTM- ASTM D-1037: standard methods of evaluating properties of wood-base fiber and particles materials. Philladelphia, 2002.

BASTOS, R. et al. Elaboração de pães com adição de farinha de sabugo de milho. Revista Ciências Exatas e Naturais, Guarapuava, v.9, n.1, p.116-128, jan./jun, 2007.

BURANELLO, R.M. Sistema privado de financiamento do agronegócio. São Paulo: Editora Quartier Latin do Brasil, 2009, 471p.

CARROL, A.; SOMERVILLE, C. Cellulosic Biofuel. Annual Review of Plant Patology, Palo Alto, v.60, p.165182, jan, 2009.

COLODETTE, J.L. et al. Influence of pulping conditions on eucalyptus kraft pulp yield, quality and bleachability. Tappi Journal, Atlanta, v.1, n1, p. 14-20, mar, 2002.

COMMERCIALSTANDARD-CS- CS 236-66: mat formed wood particle board. [S.1.], 1968.

COMPANHIANACIONALDE ABASTECIMENTOCONAB. Brasília, DF. 2011. Disponível em: <http:// www.conab.gov.br>. Acesso em: 23 de Abril de 2012.

\section{DACOSTA, L.P.E.; HASELEIN. C.L.; SANTINI E.J.}

Qualidade das chapas de partículas aglomeradas fabricadas com resíduos do processamento mecânico da madeira de Pinus elliottii engelm. Ciência Florestal, Santa Maria, v.15, n.3, p.311-322, ago./set, 2005.

FAO. Food and Agriculture Organization of the United Nations. Disponível em: < http://www.fao.org>. Acesso em: 13 de abril de 2012.

GULER, G.; BUYUKSARI, U. Effect of production parameters on the physical and mechanical properties of particleboards made from peanut (Arachis hypogaea L.) hull. BioResources, Duzce, v.6, n.4, p.5027-5036, ago./ out. 2011.

IWAKIRI, S. Painéis de madeira reconstituída. Curitiba: UFPR, 2005, 274 p.

MALONEY, T. M. Modern particleboard and dryprocess fiberboard manufacturing. São Francisco: Miller Freeman Inc., 1993, 2ed. 689 p.

MELO, R. R. et al. Propriedades físico-mecânicas de painéis aglomerados produzidos com diferentes proporções de madeira e casca de arroz. Ciência Florestal, Santa Maria, v.19, n. 3/4, p.449-460, jul./dez, 2009.

MENDES, R.F. et al. Painéis aglomerados produzidos com bagaço de cana em associação com madeira de eucalipto. Scientia Forestalis, Piracicaba, v.38, n.86, p.285-295, jun, 2010a.

MENDES, R. F. et al. Efeito da incorporação de casca de café nas propriedades físico-mecânicas de painéis aglomerados de Eucalyptus urophylla S.T. Blake. Ciência e Agrotecnologia, Lavras, v.34, n.3, p.610-617, maio/jun, 2010b.

MENDES, R. F. et al. Efeito da associação de bagaço de cana, do tipo e do teor de adesivo na produção de painéis aglomerados . Ciência Florestal, Santa Maria, v.22, n.1, p.161-170, jan./mar, 2012.

MORAIS, S.A.L.; NASCIMENTO, E.A.; MELO. D.C. Análise da madeira de pinus oocarpa parte i - estudo dos constituintes macromoleculares e extrativos voláteis. Revista Árvore, Viçosa, v.29, n.3, p.461-470, abr, 2005.

\section{NORMEN FÜR HOLZFASERPLATEN SPANPLATTEN SPERRHOLZ. DIN 52362. In:___ Testing of wood chipboards bending test, determination of bending strength. Berlin, 1982. p.39-40.}

ROWELL, R.M.; HAN, J.S.; ROWELL, J.S.

Characterization and factors affecting fiber properties. In: FROLLINI, E.; LEÃO, A.L.; MATTOSO, L.H.C. (Eds.). Natural polymers and agrofibers based composites: section II, agrofibers composites. São Carlos: Embrapa Instrumentação Agropecuária, p.115$134,2000$. 
SEKALUVU, L.; TUMUTEGYEREIZE, P.; KIGGUNDU, $\mathrm{N}$. Investigation of factors affecting the production and properties of maize cob-particleboards. Waste Biomass Valor, Kampala, 6p. mar. 2013. Disponível em: $<$ http://link.springer.com/article/10.1007/s12649-0139228-9/fulltext.html>. Acesso em: 21 mar, 2013.

SWEET, M. S.; WINANDY, J. E. The influence of degree of polymerization (DP) of cellulose and hemicellulose on the strength loss of fire-retardanttreated wood. Holzforschung, Berlin, v.53, n.3, p.311317, nov, 1999.

YRJAS, P.; LISA, K.; HUPA, M. Comparison of $\mathrm{SO}_{2}$ capture capacities of limestones and dolomites under pressure. Fuel, Turku, v.74, n.3, p.395-400, mar. 1995. 